\title{
Analysis of Channel and Structure of Cattle Marketing Intermediaries in Mubi Local Government Area of Adamawa State, Nigeria.
}

\author{
Musa Y.M, Iheanacho A.C, Nyiatagher Z.T
}

\author{
Department of Agribusiness, University of Agriculture, Makurdi, Benue State Nigeria.
}

\begin{abstract}
This study determined the Marketing Channel and Structure of Cattle among Intermediaries in Mubi Local Government Area of Adamawa State, Nigeria. Objectives of this study area to examine the marketing channel for cattle; determine the marketing structure of the intermediaries and identifying the major constraints in cattle marketing in the study area. Simple random sampling technique was employed to select 123 respondents in Mubi International Cattle Market. Primary data were collected through the use of structured questionnaire from the market. Descriptive statistics and Gini-coefficient were used in analyse the data of this study. The result shows that $87 \%$ sell live cattle, $13 \%$ sell butcher pieces, while $61.8 \%$ and $27.6 \%$ sell their cattle in secondary and terminal markets respectively. About $73 \%$ had their major source of trading cattle in north-east and $26 \%$ are from other countries (Cameroon, Chad and Niger). Gini- coefficients of 0.5673, $0.6340,0.452$ and 0.5719 were obtained for wholesalers, retailers, butchers and brokers respectively, while Respondents indicates that insurgency (insecurity) (78\%), inadequate market information (74\%), inadequate credit facility (73.2\%), cost of transportation (72.4\%), double charges by market officials been the least (48.8\%) were some of the major constraints. The study recommended that good roads, better and cheap means of transportation should be provided to the marketers through their cooperatives.
\end{abstract}

Keywords- Channel, Structure, Cattle Marketing, Intermediaries, Mubi and Nigeria.

\section{INTRODUCTION}

Nigeria is one of the leading countries in cattle production in sub-Saharan Africa (World Health Organization, 2008, World Bank 2009). The population figure of domestic livestock in Nigeria in 2011 stood at 19.5 million cattle, consisting of 3.2 million milking cows and 16. 3 million beef cattle, where Less than $1 \%$ of these populations of cattle are managed at commercially level while the $99 \%$ of the remaining population are managed traditional level (Tibi and Aphunu ,2010). Livestock production in Nigeria had been predominately rural until recently when development in husbandry and breeding for improvement was given a prominence of place. Generally, livestock husbandry plays a very important role in the development of a nation. The limited supply of animal protein in tropical countries like Nigeria is primarily the result of low productions owing to traditional management, rather than small number of the animals (Olayide, 1980). The trend is likely to continue unless animal production efficiency through the use of improved breeds is greatly increased (Umar et al, 2008), and marketing systems perfected, therefore, it is believed that livestock marketing in Nigeria is traditional with a strong cultural control. It is also believed that unfavorable marketing outcome discourages production through lower output prices and consumption through high prices (Iheanacho, 2005).

Agricultural contribution to the nation's GDP is 35\%, whereas livestock contributed only 5\% (Bonnet et al, 2013). Cattle industry provides a means of livelihood for the significant proportion of the livestock rearing household and participant in the cattle value chain in Nigeria (Okunmadewa 1999). Although there are many sources of animal protein in Nigeria, recent study (Tibi and Aphumu 2010) has shown that cattle and cattle product are predominant and the most commonly consumed animal protein sources. Thus, they are highly value livestock in Nigeria where they are kept for beef, hide and milk. Cattle and beef trade provide the largest market in Nigeria with millions of Nigerians making livelihood from various beef related enterprises (Umar et al, (2008).

According to Bonnet et al, (2013), the strong demand for animal product is not only due to high rate of urbanization (60\% of Nigerians are city dwellers), but above all, to consumers' greater purchasing power and emergence of new middle class. Furthermore, this trade giant accounts for nearly $60 \%$ international trade in the region. The demand for beef is up to 17,466 tones per day whereas the supply is just 3,999 tones (Oyekale 2001). Supply of cattle and 
itsproducts has witnessed a decline in the years 2010 2015. The per capita consumption of beef in Nigeria stood as $\mathrm{N} 4568.4, \mathrm{~N} 4356.2, \mathrm{~N} 4356.2, \mathrm{~N} 4202.4$ and $\mathrm{N} 4021.4$ respectively, (National Chicken Council 2012), due partly to population growth and deficit in supply, with import at 25\% (Bonnet et al, 2013). The high cost of marketing cattle is often the commonly cited culprit for this situation. Efficient marketing plays an important role in the attempt to achieve wider accessibility and affordability of any product to consumers (Mafimisebi et al, 2011). This is obvious from the long established maxim that production and marketing constitute a continuum, thus, lack of development in one will necessarily obstruct development in the other (Olayemi,S 2004; Olayemi, 1994; Seperich et.al, 2002).

\section{Objectives of the Study}

The main objectives of this study were to determine the marketing channel and the marketing structure of intermediaries in cattle marketing in Mubi Local Government Area of Adamawa state, Nigeria.
The specific objectives were to:

i. the marketing channels for cattle in the study area;

ii. determine the marketing structures of the intermediaries in cattle marketing; and

iii. examine the major constraints in cattle marketing.

\section{METHODOLOGY}

\section{Study Area}

The study was conducted in Mubi Area of Adamawa State, Nigeria. Mubi is located on latitudes $8^{0} \mathrm{~N}$ and $11^{\circ} \mathrm{N}$ and longitudes $11^{0} 5^{\prime} \mathrm{E}$ and $13^{\circ} 5^{\prime} \mathrm{E}$. It is on altitude of 696 meters above sea level, with an annual mean rainfall of $700 \mathrm{~mm}$ in North West and $1600 \mathrm{~mm}$ in the Southern part of the State. The Maximum temperature can reach $40^{\circ} \mathrm{C}$, particularly in April, while minimum temperature can be as low as $18^{\circ} \mathrm{C}$ between December and January (Mansir, 2006). It also has an international boundary with the Cameroon Republic along its eastern border (Mubi et al, 2013).

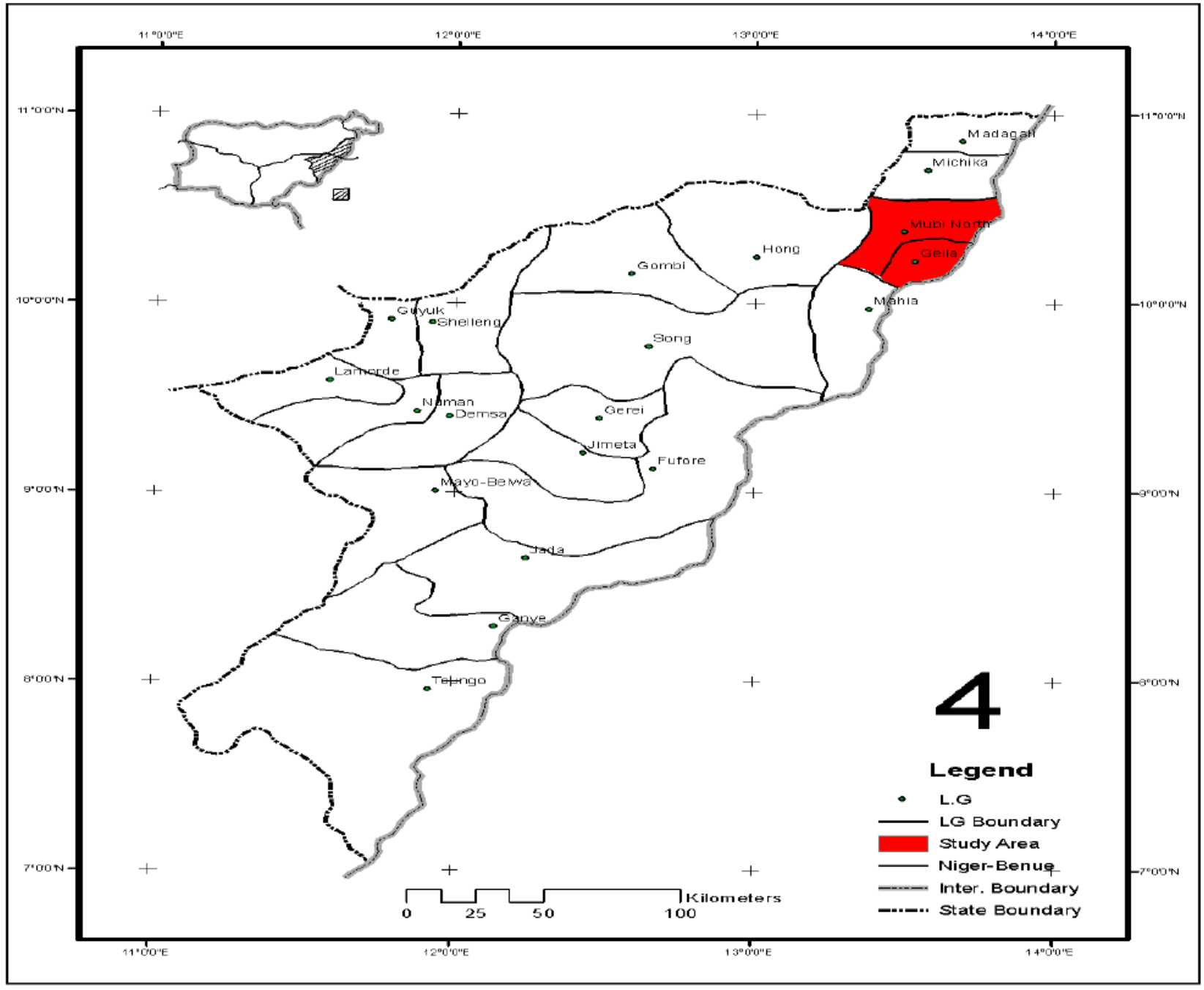

SOURCE: Adamawa Agricultural Development Program, (1986).

Fig. 1: Map of Adamawa State showing the Study Area. 
The area is divided into two LGAs which are Mubi north and Mubi south. Mubi North has a population of 151072 people and Mubi south has a population of 128937 people (National Population Commission, 2006). They are two (2) important LGAs among the 21 LGAs of the State. Mubi International Cattle Market which is situated in Mubi south LGA of Adanawa State, forms an area of contact with cattle marketers. Figure 1 shows the Map of Adamawa State Nigeria.

\section{Population and Sampling Procedure}

The population of this study comprises all Cattle Marketers' in Mubi International Cattle Market. A sample of 123 was selected from the population of all the cattle marketers in the study area. It was selected using simple random sampling technique, from a sample frame of $50 \%$ of 246 respondents of cattle market intermediaries in Mubi International Cattle Markets.

\section{Data Collection and Analysis}

The data for the study were obtained from primary source, using well structured questionnaire administered to the cattle marketers. Data were collected on the marketing channels, sales, returns and constraints. Descriptive statistics were used to analyses the marketing channel and the major constraint affecting cattle marketing. Gini coefficient was used in analyzing the marketing structure of the intermediaries and it is expressed as fallows:

Where,

$$
\text { G.C }=1-\sum \mathrm{XY}
$$

$\mathrm{GC}=$ Gini Coefficient.

$\mathrm{X}=$ proportion of cattle marketers

$\mathrm{Y}=$ cumulative proportion of cattle marketers earnings

$\Sigma=$ summation sign

\section{RESULTS AND DISCUSSION}

\section{Marketing Channels}

The marketing channels for cattle in Adamawa State are presented in Table 1 and figure 2. The result shows that $87 \%$ of the respondents sold live cattle, while $13 \%$ sold butchered pieces to the consumers in the markets and other village markets. Majority $(61.8 \%)$ of the respondents sold their cattle in a secondary market. These are people who buy in the market and still sell it in the market. Also 27.6\% sold their animals in a terminal or urban market. These are people who transport those cattle to other parts of the states and countries, while $10.6 \%$ of the respondents sold there cattle and its product in a primary or village markets.

Majority (62.6\%) transport their cattle from place to place using truck/ lorry and few (37.4\%) by trekking. Some of the respondents around the border of the country come in with their cattle by trekking to avoid some charges. Most $(43.9 \%)$ of the respondents found in the markets are sellers, $36.6 \%$ buyers, while $19.5 \%$ are agents who are responsible for bringing the buyers and the sellers together. This also agrees with Okewu and Iheanacho (2015), who stated that the major market players are wholesalers, retailer and butchers who sell to one another and directly to final consumers in small quantities. Majority $(82.1 \%)$ of the respondents sell their cattle to gain money so as to continue with business, while $17.9 \%$ are buyers and sellers within the market.

Most (78\%) of the respondents gave resale as the primary reason for buying cattle, $11.4 \%$ for consumption, and $10.6 \%$ for breeding. Few (26\%) of the marketers sourced their traded cattle from other countries around, which include Chad and Cameroon, while $<1 \%$ from North West. Majorities (73.2\%) of the cattle traded are from north eastern part of the country, and larger population of the cattle producers is concentrated in that region. Majority (87.8\%) used their personal saving for cattle marketing and $12.2 \%$ used personal savings and loans as their sources of fund. Most (39\%) of the marketers purchased Red Bororo as the breed of cattle been marketed, 26\% White Fulani, $4.1 \%$ Sokoto Gudali and majority (76.4\%) of those cattle are mostly sold in secondary markets.

Marketing channel for cattle shows a systematic movement of cattle from the producer to the consumers. The analysis of marketing channel for cattle in figure 2 indicates that the production is mostly done by cattle rearers (Fulani). The cattle rearer sells the cattle to the wholesaler and the local marketers, while local marketers sell to the wholesalers. The linkage between cattle rearers and butchers is a weak one. Cattle rearers only sell to butchers when in course of migration, any cattle fall sick. A butcher is then invited to purchase it. The wholesalers are responsible for selling the cattle to the retailers, butchers and brokers, whereas the retailers are responsible for selling the cattle to the butchers, brokers and consumers. The butchers and the brokers also sell their cattle to the consumers who are at the receiving end. This means that trading of cattle passes through many intermediaries before getting to the hand of the final consumers (William, et al, (2006). Transportation is the only value addition in the marketing channel, as there are no processors along the channel. 
Table.3: Marketing channels of cattle markets $(n=123)$

\begin{tabular}{|c|c|c|}
\hline Variables & Frequency & Percentage \\
\hline \multicolumn{3}{|l|}{ In what form do you sell your cattle. } \\
\hline live cattle & 107 & 87 \\
\hline butchered pieces & 16 & 13 \\
\hline \multicolumn{3}{|l|}{ Where do you sale your cattle } \\
\hline primary market & 13 & 10.6 \\
\hline secondary market & 76 & 61.8 \\
\hline terminal market & 34 & 27.6 \\
\hline \multicolumn{3}{|l|}{ Mode of transporting your cattle } \\
\hline trekking & 46 & 37.4 \\
\hline lorry/truck & 77 & 62.6 \\
\hline \multicolumn{3}{|l|}{ Major role in cattle marketing } \\
\hline seller & 54 & 43.9 \\
\hline buyer & 45 & 36.6 \\
\hline agent & 24 & 19.5 \\
\hline \multicolumn{3}{|l|}{ Reason for selling your cattle } \\
\hline money & 101 & 82.1 \\
\hline resale & 22 & 17.9 \\
\hline \multicolumn{3}{|l|}{ Reason for buying your cattle } \\
\hline consumption & 14 & 11.4 \\
\hline resale & 96 & 78 \\
\hline breeding & 13 & 10.6 \\
\hline \multicolumn{3}{|l|}{ Major source of traded cattle } \\
\hline North-east Nigeria & 90 & 73.2 \\
\hline North-west Nigeria & 1 & 0.8 \\
\hline others ( Cameroon, Chad and Niger) & 32 & 26 \\
\hline \multicolumn{3}{|l|}{ Major source of fund } \\
\hline personal saving & 108 & 87.7 \\
\hline personal saving/loan & 15 & 12.3 \\
\hline \multicolumn{3}{|l|}{ Breed of cattle marketed } \\
\hline white fulani & 32 & 26 \\
\hline red bororo & 48 & 39 \\
\hline bokoloji & 14 & 11.4 \\
\hline sokoto gudali & 5 & 4.1 \\
\hline white fulani/red bororo & 17 & 13.8 \\
\hline white fulani/bokoloji & 5 & 4.1 \\
\hline white fulani/red bororo/bokoloji & 2 & 1.6 \\
\hline \multicolumn{3}{|l|}{ Origin of cattle sold } \\
\hline primary market & 29 & 23.6 \\
\hline secondary market & 94 & 76.4 \\
\hline
\end{tabular}

Source: Field survey data, 2017 


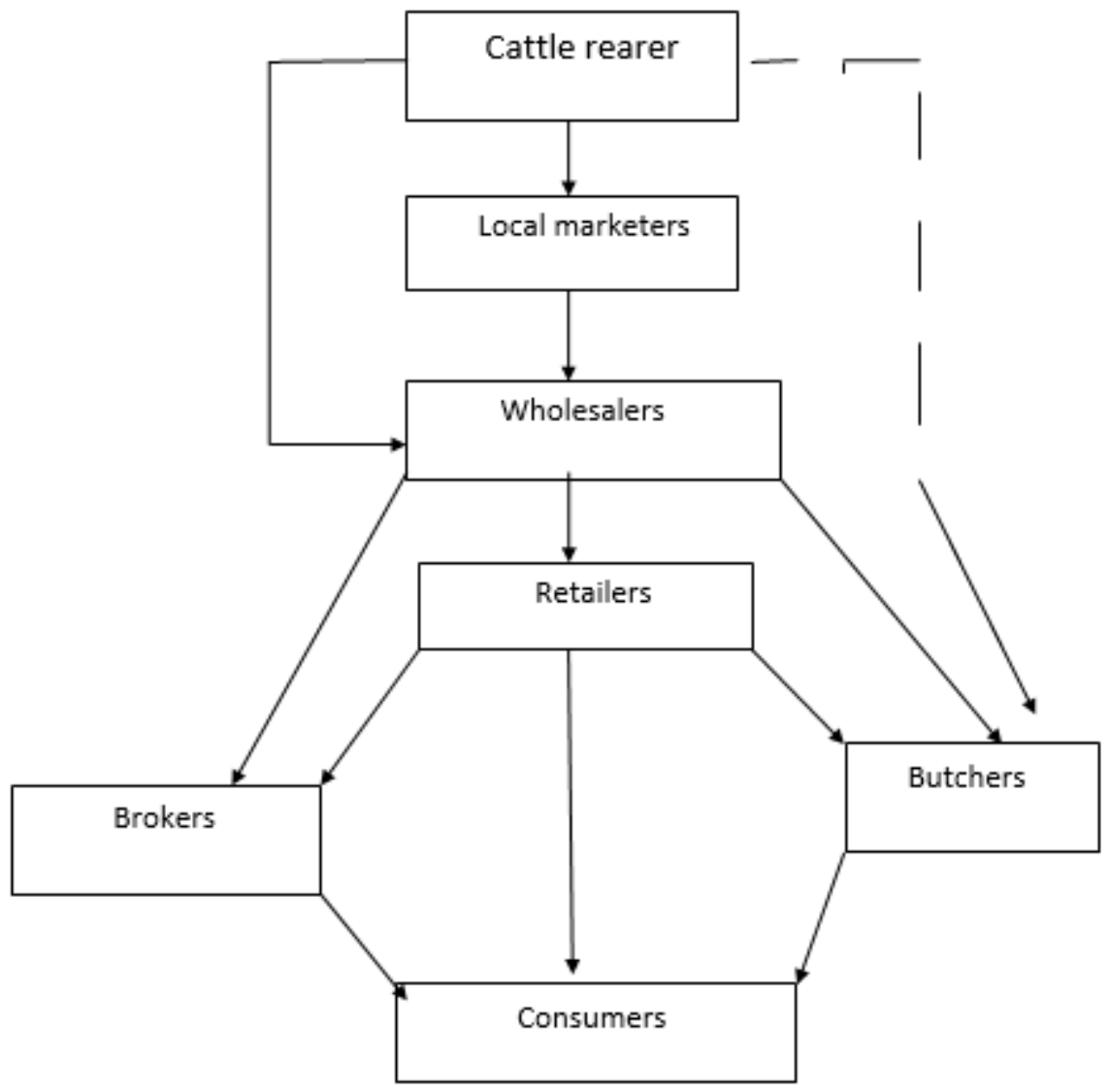

Fig.2: Marketing Channel of Cattle in Adamawa State, Nigeria

KEY:

Strong linkage

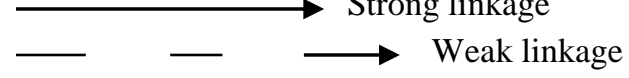

\section{Marketing Structure of the intermediaries}

The cattle marketing characteristics in the study area is highly dependent upon the structure of the market. The result of Gini coefficient of market intermediaries are shown in Table 2. The results indicated that the wholesalers had total weekly sales and mean value of weekly sales of $\$ 9,275,000,030$ and $\$ 15,458,333.83$. The results indicate that the wholesales cattle market was concentrated, with Gini coefficient of 0.5673 , which shows the possibility of non-competition in the markets. The market is controlled by fewer individuals and there is inequality distribution of wealth in the markets, for the retailers markets, it showed that they had total weekly sales and mean weekly sales of $\$ 44,600,014$ and $\$ 1,651,852.37$. These findings show that the retail market is more competitive with Gini coefficient of 0.6340, compared with the wholesalers (0.5673), and maximum inequality in income distribution and market concentration. (Iheanacho \& Mshelia 2004), in cattle retail market, on the other hand, high capital investment makes entry easy. This makes sellers concentration moderate or less, and this is on average. It is an indication of lower profit due to presence of many buyers and sellers.

For the butchers they had total weekly sales and mean weekly sale of $\$ 9000,007.5$ and $\$ 600,000.5$. These findings revealed that the butchers market was competitive with low Gini coefficient of 0.4552 , which shows that people are not ready to go into business that demand more cash because they are afraid of risk. Whereas the brokers' market analysis shows that they had total weekly sales and mean weekly sales for brokers was $25,800,010.5$ and $\$ 1,228,571.93$. The broker's market shows market concentration with a Gini coefficient of 0.5719 , showing that there is unequal distribution of wealth among them like the wholesales and brokers and non-competition. 
Table.2: Weekly Sales Distribution of Cattle Market Intermediaries in Adamawa State, Nigeria.

\begin{tabular}{llllll}
\hline $\begin{array}{l}\text { Market } \\
\text { Intermediaries }\end{array}$ & $\begin{array}{l}\text { Total no. of } \\
\text { Intermediaries }\end{array}$ & $\begin{array}{l}\text { Total Weekly } \\
\text { Sales ( }\end{array}$ & $\begin{array}{l}\text { Mean Value } \\
\text { of Geekly } \\
\text { Sales (\$) }\end{array}$ & $\begin{array}{l}\text { Gini } \\
\text { Coefficient }\end{array}$ & $\begin{array}{l}\text { Market } \\
\text { Structure }\end{array}$ \\
\hline Wholesalers & 60 & $9,275,000,030$ & $15,458,333.83$ & 0.5673 & Concentrated \\
Retailers & 27 & $44,600,014$ & $1,651,852.37$ & 0.6340 & Concentrated \\
Butchers & 15 & $9,000,007.5$ & $600,000.5$ & 0.4550 & $\begin{array}{l}\text { Non- } \\
\text { concentrated } \\
\text { Concentrated }\end{array}$ \\
\hline
\end{tabular}

Source: Field survey data, 2017

\section{Major Constraints in Cattle Marketing}

Major constraints in cattle marketing in the study area are show in Table 3. The finding reveals that insurgency (insecurity) was indicated by $78 \%$ of the respondents as a major problem and this result from the activities of Boko haram. This was followed by inadequate market information (74\%) on price and cost of production, which are not made available to the cattle marketers. Inadequate market facilities (73.2\%) such as improper housing, absence of portable water, unit of measurement, lighting point and higher cost of transportation (72.4\%) make it difficult for marketers to meet up with market days some times. The only means of transportation available are trekking and trucks. Other constraints include, low profitability (65\%) and inadequate credit facility (52\%), resulting in high interest rate, absence of collateral and improper record keeping by the marketers which are needed by lending institutions. Also double charges by market official were the least $(48.8 \%)$ constraint. These include charges by Local, State and Federal Governments, and Kungiyan Miyoti Allah. These are some of the major constraints that affect cattle marketing in Adamawa State, Nigeria. This agrees with study by Okewu and Iheanacho (2015), which reveals that inadequate market information, credit, market facilities , high cost of acquisition, transportation, medication and feeding, as well as the unethical charges and levies by crook officials, especially those along the produce checking points from Local Government to Local Government are the major marketing constraints in cattle marketing.

Table.3: Major constraints in cattle marketing

\begin{tabular}{lll}
\hline Constraints & Frequency & Percentage \\
\hline Inadequate market information & 91 & 74.0 \\
Cost of transportation & 89 & 72.4 \\
Cost of acquisition of Cattle & 69 & 56.1 \\
Cost of medication & 61 & 49.6 \\
Double charges & 60 & 48.8 \\
Inadequate credit facility & 64 & 52.0 \\
Low profitability & 80 & 65.0 \\
Inadequate market facility & 90 & 73.2 \\
Insurgency & 96 & 78.0 \\
\hline
\end{tabular}

*Multiple responses existed, hence>100\%

Source: Field survey data, 2017

\section{CONCLUSION AND RECOMMENDATIONS}

Marketing channel and structure of cattle among intermediaries in the study area revealed that $87 \%$ sell live cattle, $13 \%$ sell butcher pieces, while $61.8 \%$ and $27.6 \%$ sell their cattle in secondary and terminal markets respectively. Gini- coefficients of $0.5673,0.6340,0.452$ and 0.5719 were obtained for wholesalers, retailers, butchers and brokers respectively, indicating non-competition for wholesalers, brokers and retailers but butchers having a level of competition in the markets. Insurgency/insecurity, inadequate market information, inadequate market facility, cost of transportation, double charges by markets official were some of major the constraints in cattle marketing 
which shows that the market need to be improved in the area of security. The study, therefore recommended that; extension workers should be well equipped to provide market information on cattle marketing in the study area, good roads, better and cheap means of transportation should be provide to the marketers through their cooperatives, while lending institutions should be encouraged to advance soft loans to the marketers to reduce the problems of cost of acquisition and inadequate capital among the cattle marketers in the state. Finally there should be rules and regulations on tax collection especially through the cooperatives to tackle the problems of double charges on the marketers.

\section{REFERENCES}

[1] ADADP (1986). Adamawa Agricultural Development Program.

[2] Bonnet. B, Berterand. G and Christophe. B (2013kkk), Demand for farm animal product

[3] in Nigeria an opportunity for sahel countries Accued $>$ Publication>grain desel.magazine>51 special issue Nigeria

[4] Ihenacho, A. C.(2005).Structural Characteristics and performance of Retail Marketing of Eggs in Maiduguri Metropolis of Borno State, Nigeria; Journal of Sustainable Development in Agriculture and Environment, 1: 70-76. Vol.1 p 13-14.

[5] Iheanacho, A.C. and Mshelia, S.I. (2004).Economics of local rice marketing in Adamawa State

[6] of Nigeria. Nigeria Journal of Agricultural Research Development, 4(2):69-76. In Adamawa. Centre for research training and development, Uk. 1(2), 1-5.

[7] Mafimisebi. T. E, Oguntade, A. E, Fajeminsin N. A and Ayelari P. O.(2011): Local Knowledge and Socio Economic Determinants of Traditional Medicines' Utilization in Livestock Health Managements in South West Nigeria. Journal of Ethnobiology and Ethno medicine, January 2012. 16 (30): 34-42

[8] Mansir. M. (2006).Livestock marketing and transportation in Nigeria. expro@erols.com.

[9] Mubi,A.A,Michika,S.A and Midau,A (2013). Cattle Marketing in Mubi Area of Adamawa State, Nigeria. Department of Animal Production, Adamawa State University, Mubi Nigeria and Ministry for Livestock and Nomadic Settlement, Adamawa State, Nigeria . Agricultural and Biology Journal of North America Vol 4.3.199.198 Science Huß, http://www.scihub.org/ABJN [10] NCC (2012), National Chicken Council
[11] National Population Commission (2006). National population census, Federal Republic of Nigeria Official Gazette, 94, Lagos.

[12] Okali,C. and Obi,A.(1982). A Preliminary report on supply and price of ruminant in elected market in Oyo state, Nigeria. (Unedited Draft).

[13] Olayemi, J. K. (1994). Scope for the Development of the Food Marketing System in Ibadan, Nigeria. FAO Report, pp.1-29

[14] Olayemi, S. (2004). Marketing of Smoked fish in some local government Area of Niger State" unpublished Department of Agricultural Economics and Extension Technology, School of Agriculture and Agricultural Technology. Federal University of Technology Minna, Nigeria.

[15] Olayide. S. O. (1980). Nigeria small farmers problem and Prospective integrated rural development. International journal of Agricultural science 2(1):212239

[16] Oyekale.A.S., (2001), Supply and Demand equations' for livestock products in Nigeria; A simultaneous equation approach. Nigerian journal of Animal science ISSN 1119. 4 (2): 117- 125.

[17] Okunmadewa, F. Y. (1999):Livestock Industry as a Tool for Poverty Alleviation. Tropical Journal of Animal Science 2(2): 21-30

[18] Okewu, J. and Iheanacho, A. C. (2015), The Marketing Channels and Chains for Goats in Benue State, Nigeria . ARC Journal of Academic research www.africareseachcorps,com volumel.issue 1 pp.51 70 .

[19] Okewu, J. and Iheanacho, A.C. (2015), Socio-economic Characteristics of Goat Marketers in Benue State, Nigeria ARC Journal of Social Sciences and Humanities (ARC-JSSH) Volume 1, Issue 1, pages 54 - 66 www.africaresearchcorps.com

[20] Seperich, G. J.,Woolverton, M. W. and Beirlein, J. G. (2002). Introduction to Agribusiness Marketing, Prentice Hall, Pearson Education Company, Upper River, NJ, ISBN 0-13-486382-8

[21] Tibi, K.N. and Aphunu, A. (2010). Analysis of Cattle Market in Delta State: The Supply Determinants. African Journal of General Agriculture. Vol. 6, (4): 199-203.

[22] Umar, A.S., Alamu, J.F. and Adeniyi, O.B. (2008): Economic Analysi Small-scale Cow Fattening Enterprise in Bama Local Government of Borno State, Nigeria, Tropical Journal of Animal Science, 1(4):27-39 
[23] World Bank, (2009). World Bank assistance to Agriculture in sub-Saharan Africa: Independent Evaluation Group (IEG) Review.Available at: http://siteresources.worldbank.org/EXTASSAGRISUBS AHAFR/Resources/ag_africa_eval.pdf (Accessed on October 1, 2011)

[24] World Health Organization, (2008), Agriculture in SubSaharan Africa: Prospect and challenges for the next decade

[25] Williams T.O; Spycher B and Okike I (2016) improving livestock marketing and intra-regional trade in West Africa. Determining appropriate Economic incentive and Police frame work international livestock research institution (IIRI) Nairobi, Kenya pp122. 